\title{
EVALUACIJA STRUČNE PRAKSE NA OSNOVNIM AKADEMSKIM STUDIJAMA SOCIJALNE POLITIKE I SOCIJALNOG RADA ${ }^{1}$
}

\author{
Ljiljana Skrobić2, Bojana Pucarević, Ivan Anđelković \\ Univerzitet u Nišu, Filozofski fakultet, Departman za socijalnu \\ politiku i socijalni rad
}

\begin{abstract}
Apstrakt: S obzirom na to da je socijalni rad praktično zasnovana profesija, stručna praksa zauzima značajno mesto u obrazovanju socijalnih radnika. Prepoznate su brojne prednosti koje stručna praksa ima za studente, kako u domenu profesionalnog, tako i u domenu ličnog razvoja. U skladu sa tim značajno je kontinuirano evaluirati i unapređivati stručnu praksu na studijama socijalnog rada. Cilj rada je prikaz evaluacije stručne prakse na Osnovnim akademskim studijama socijalne politike i socijalnog rada Filozofskog fakulteta u Nišu. Evaluacija je sprovedena kroz analizu sadržaja studentskih Izveštaja o obavljenoj stručnoj praksi. Urađena je evaluacija praksi koje su realizovane u toku školske 2018/2019. godine. Rezultati evaluacije pokazuju da je realizovana stručna praksa delimično, ali ne i potpuno usklađena sa ciljevima, očekivanim ishodima i sadržajima prakse koji su predviđeni studijskima programom. Dalji pravci razvoja stručne prakse na Departmanu za socijalnu politiku i socijalni rad u narednom periodu treba da budu usmereni ka što većem usklađivanju sa studijskim programom, kao i propisanim Standardima praktične obuke u obrazovanju socijalnih radnika.
\end{abstract}

Ključne reči: socijalni rad, obrazovanje, stručna praksa, studenti.

\section{Uvod}

U međunarodnoj literaturi koriste se različiti termini kako bi se opisale iste ili slične aktivnosti u praktičnom delu obrazovanja socijalnih radnika. Neki od njih su „praktično učenje” (practice learning), „teresnki rad” (fieldwork), „terenska praksa" (fieldwork practice), praktikum (practicum) (Papouli, 2014). Standardi praktične obuke u obrazovanju socijalnih radnika koji su kreirani u Srbiji 2016. godine (Hrnčić i sar., 2016) previđaju postojanje dva oblika praktične obuke: praktičnu nastavu

\footnotetext{
${ }^{1}$ Rad je nastao u okviru projekta „Jačanje kapaciteta osnovnih akademskih studija socijalne politike $i$ socijalnog rada" koji je realizovao Departman za socijalnu politiku i socijalni rad Filozofskog fakulteta u Nišu tokom školske 2018/2019. godine.

${ }^{2}$ ljiljana.skrobic@filfak.ni.ac.rs
} 
i terensku praksu. Za razliku od praktične nastave koja se izvodi u okviru redovne nastave, kao sastavni deo predmeta, kurseva ili modula, terenska praksa ima status obaveznog predmeta, koji se zasebno realizuje tokom više studijskih godina u različitim organizacijama, čime se obezbeđuje kontinuitet, raznovrsnost praktičnih iskustava i mogućnost postepenog profesionalnog razvoja. Terenska praksa se odvija van fakulteta, u obliku posebnih kurseva, predmeta ili modula koji predstavljaju jedinstvenu celinu sa jasno definisanim ciljevima i očekivanim ishodima učenja (Hrnčić i sar., 2016: 124). Termin i sadržaj termina „terenska praksa“ ekvivalentan je terminu „stručna praksa“ koji se koristi na Departmanu za socijalnu politiku i socijalni rad Filozofskog fakulteta u Nišu.

Stručna praksa je sastavni deo većine kurikuluma za obrazovanje socijalnih radnika, a na Departmanu za socijalnu politiku i socijalni rad Filozofskog fakulteta u Nišu na osnovnim akademskim studijama, počevši od druge godine studija, realizuje se pet stručnih praksi. Stručna praksa se realizuje u različitim ustanovama socijalne i zdravstvene zaštite koje su relevantne za profesiju socijalnog radnika. S obzirom na to da je nastava na Departmanu započeta je u školskoj 2016/2017. godini, a da Standardi praktične obuke u obrazovanju socijalnih radnika predviđaju da se kurikulum terenske prakse redovno preispituje, prilagođava i razvija u skladu sa potrebama i okolnostima u kojima se realizuje (Hrnčić i sar., 2016) prepoznali smo da je značajno uraditi evaluaciju nakon prvog ciklusa realizovanih stručnih praksi.

Cilj rada je prikaz evaluacije stručne prakse na osnovnim akademskim studijama socijalne politike i socijalnog rada. Evaluacija stručne prakse je urađena kao jedna od aktivnosti projekta „Jačanje kapaciteta osnovnih akademskih studija socijalne politike i socijalnog rada" koji je realizovao Departman za socijalnu politiku i socijalni rad Filozofskog fakulteta u Nišu tokom školske 2018/2019. godine. U radu će, pored rezultata sprovedene evaluacije, biti prikazani i značaj stručne prakse u obrazovanju socijalnih radnika, koncept stručne prakse na Departmanu za socijalnu politiku i socijalni rad, kao i preporuke za unapređenje kvaliteta stručne prakse.

\section{Značaj stručne prakse}

S obzirom na to da je socijalni rad praktično zasnovana profesija (practicedbased profession) (IFSW/IASSW, 2014), učenju kroz praksu se posvećuje veliki značaj. Ovo nije odlika samo savremenih kurikuluma, već se ovom pitanju od početka obrazovanja socijalnih radnika pridavala velika pažnja (Papouli, 2014). Praksa se čak naziva i osnovnom komponentnom procesa obrazovanja socijalnih radnika (Papouli, 2014) i opisuje se kao mesto gde se teorija, etika i veštine sastaju (Lager \& Cooke Robbins, 2004). U aktulenom trenutku, kada problemi prakse socijalnog rada postaju sve kompeksniji, posebno se naglašava značaj studentske prakse u procesu profesionalnog osposobljavanja (Urbanac, 2003).

Prednosti učenja kroz stručnu praksu za studente su višestruke. To je prilika da se kroz aktivno učešće prodube i steknu nova znanja, veštine i vrednosti relevantne za profesiji socijanog rada. Praksa omogućava integrisanje teorije sa praksom, „te- 
stiranje" onoga što se uči u učionici, povezivanje sa profesijom, građenje profesionalnog identiteta, priliku za razrešavanje etičkh dilema i pravljenje izbora u vezi sa njima, razvoj kulturne osetiljivosti i kompetentnosti (Lager \& Robbins, 2004).

Pored nesumnjivog značaja prakse za profesionalni razvoj budućih socijalnih radnika, praksa se prepoznaje kao veoma značajna i za lični razvoj (Papouli, 2014). Tokom prakse studenti se, kroz direktan i indirektan kontakt, sreću sa različitim kategorijama ljudi, kako korisinika tako i profesionalaca. Svaku od ovih individua, grupa, zajednica odlikuju različite karakteristike ličnosti, ponašanja, vrednosti, konteksta iz kojih dolaze. Ovo iskustvo omogućava studentima da se suoče i preispitaju svoje ideje, stavove, predrasude u odnosu na druge, da osveste svoju senzitivisanost za rad sa određenim kategorijama ljudi, ali i da u realnom kontekstu profesonalnog okruženja uče da upravljaju svojim emocijama i ponašanjima.

\section{Stručna praksa na Departmanu za socijalnu politiku i socijalni rad Filozofskog fakulteta u Nišu}

Akreditovanim programom osnovnih akademskih studija socijalne politike $\mathrm{i}$ socijalnog rada iz 2016. godine predviđena je realizacija pet stručnih praksi u trajanju od po 50 sati. Studenti obavljaju stručnu praksu u ustanovama socijalne i zdravstvene zaštite. Praksa 1 se realizuje u Centru za socijalni rad i Centru za porodični smeštaj i usvojenje, Praksa 2 u Domu za decu bez roditeljskog staranja i Zavodu za vaspitanje dece i omladine, Praksa 3 u Klinici za zaštitu mentalnog zdravlja u Nišu, praksa 4 u Specijalnoj psihijatrijskoj bolnici Gornja Toponica i praksa 5 u Gerontološkom centru. Nakon realizovane prakse, studenti popunjavaju Izveštaj o obavljenoj stručnoj praksi i imaju usmenu odbranu Izveštaja.

Studijskim programom su definisani ciljevi, očekivani ishodi i sadržaj stručne prakse. Ciljevi prakse obuhvataju: upoznavanje načina funkcionisanja i sadržaja delatnosti ustanova, upoznavanje sa poslovima i metodologijom rada socijalnog radnika u oblastima koje pokrivaju rad socijalnog radnika, upoznavanje sa različitim grupama korisnika socijalne zaštite sa kojima rade i njihovim karakteristikama, osposobljavanje za prepoznavanje problema u zajednici i primenu preventivnih, razvojnih i zaštitnih socijalnih aktivnosti. Očekivani ishodi su: poznavanje zakonskih okvira za primenu različitih postupaka i mera u oblasti socijalne zaštite, prepoznavanje $i$ diferenciranje oblasti i mogućnosti primene različitih vrsta prevencije iz domena rada socijalnog radnika, planiranje aktivnosti u sprovođenju prevencije u radu sa decom i mladim, porodicom, osobama sa invaliditetom, kao i sa odraslim i starijimm ljudima. Sadržaj stručne prakse podrazumeva učešće u različitim segmentima rada socijalnog radnika (priprema i planiranje, organizovanje, sprovođenje, evalucija).

Filozofski fakultet u Nišu je 2017. godine doneo Pravilnik o stručnoj praksi studenata socijalne politike i socijalnog rada kojim se utvrđuju uslovi i standardi za obavljanje stručne prakse.

Na Departmanu za socijalnu politiku i socijalni rad ne postoji nastavnik veština koji se bavi stručnom praksom, već to rade nastavnici i saradnici sa Departmana 
koji su angažovani na drugim predmetima. Nastavnici i saradnici koji učestvuju u organizaciji stručne prakse kao najveći izazov prepoznaju disproporciju broja studenata u odnosu na broj mentora u ustanovama u kojima se praksa realizuje. Iz tog razloga je studentima pružena mogućnost da praksu u centrima za socijalni rad realizuju van Niša, odnosno u mestima u kojima imaju prebivalište, dok su praksu u drugim ustanovama realizovali u Nišu. Iz istog razloga, broj realizovanih sati stručne prakse nije uvek bio u skladu sa satima koji su predviđeni studijskim programom.

\section{Metodološki okvir}

Evaluacija stručne prakse je urađena kroz utvrđivanje usklađenosti realizacije prakse sa ciljevima, očekivanim ishodima i sadržajima prakse koji su predviđeni studijskim programom. Urađena je evaluacija praksi koje su realizovane u toku školske 2018/2019. godine (Praksa 1, 2, 3 i 4).

Evaluacija je sprovedena kroz analizu sadržaja studentskih Izveštaja o obavljenoj stručnoj praksi. Analiza sadržaja je urađena u okviru tematskih celina koje Izveštaj sadrži (opis aktivnosti studenta/kinje u kojima je učestvovao/la, problemi i izazovi sa kojima se student/kinja susretao/la tokom prakse, pozitivna iskustva studenta/kinje tokom prakse, prikaz eventualnog nesklada između očekivanja i realnosti, prikaz povezanosti između znanja i veština stečenih tokom studija i njihove primene tokom prakse). U radu će se termin ,studenti“ odnositi i na studente i na studentkinje.

Analizirani su izveštaji 74 studenta druge i treće godine, odnosno 253 izveštaja.

\section{Rezultati i diskusija}

\subsection{Opis aktivnosti u kojima su studenti učestvovali}

Svi studenti su kroz razgovor sa mentorima i drugim stručnim radnicima imali priliku da se upoznaju sa istorijatom rada ustanova, strukturom i organizacijom rada, da obiđu fizički prostor ustanova. Studentima su usmeno predstavljeni poslovi koje obavljaju socijalni radnici, kao i drugi stručni radnici. Takođe, najveći broj studenata se na početku prakse upoznao sa normativima kojima se uređuje rad ustanove, kao i sa procedurama rada. Neki od studenata su, pre svega tokom prakse u Centru za porodični smeštaj i usvojenje, upućeni na edukativni i informativni materijal namenjen zaposlenima i hraniteljima (knjige, priručnici, brošure).

Najzastupljenija aktivnost studenata u svim ustanovama bilo je upoznavanje sa dokumentacijom i pregled dosijea korisnika i veliki broj studenata je najveći deo vremena na praksi proveo u ovoj aktivnosti. Neki od studenata su imali priliku da sa mentorima razgovaraju o slučajevima, dobiju pojašnjenja i detaljnije infromacije, dok drugi nisu imali tu priliku. Mentori su, u većoj ili manjoj meri, bili raspoloženi za ovakav vid rada sa studentima, odnosno za to da podele iskustva iz svog višegodišenjeg rada, pradstave detaljnije određene slučajeve i razgovaraju o njima. 
Može se napraviti razlika u aktivnom i pasivnom učešću studenata u različitim aktivnostima. Neki od studenata su u centrima za socijalni rad imali priliku da samostalno, a uz konsultacije i podršku mentora, obavljaju poslove koji se odnose na dokumentovanje rada (pišu pozive za korisnike, unos podataka u integrisani softverski sistem). Neki od studenata imali su priliku da prisustvuju sastancima stručnog tima, učestvuju u pisanju početne procene, plana usluga, nalaza i stručnog mišljenje.

Što se tiče kontakta sa korisnicima, u centru za socijalni rad većina studenata je, uz saglasnost korisnika, prisustvovala bar jednom intervjuu sa korisnicima. Neki su imali ulogu opservera, dok su drugi imali mogućnost da učestvuju aktivno u intervjuu. U vezi sa ovom aktivnošću, studenti kao značajne izdvajaju razgovore sa mentorima i drugim stručnim radnicima nakon obavljenih intervjua kojima su studenti prisustvovali ("...razgovor o tome kako bih ja rešila neku sitaciju, vodila razgovor, našla neka alternativna rešenja i slično" - studentkinja druge godine). Nekolko sutdenata je imalo iskustvo „direknog rada” sa korisnicima u vidu informisanja korisnika (o potrebnoj dokumentaciji za ostvarivanje prava) i provere ispravnosti dokumentacije potrebne za ostvarivanje prava. Nekoliko studenata je išlo u terensku posetu sa stručnim radnicima centara sa socijalni rad.

U Centru za porodični smeštaj i usvojenje, neki od studenata su prisustvovali sastancima stručnih radnika i hraniteljskih porodica, intervjuu sa potencijalnim hraniteljima, poseti školi i sastanku sa pedagogom, išli u terenske posete hraniteljskim porodicama. U Zavodu za vapsitanje dece i omladine, Domu za decu bez roditeljskog staranja i zdravstvenim ustanovama, najveći broj studenata je ostvario u nekoj meri kontakt sa korisnicima. U Zavodu za vaspitanje su razgovarali sa mladima smeštenim u toj ustanovi, dok su u okviru Domske zajednice Doma za decu imali priliku da pored razgovora učestvuju i u igri sa decom i mladima (igre memorije, slaganje slagalice). Tokom prakse u Klinici za mentalno zdravlje studenti su prisustvovali grupnom radu sa pacijentima koji boluju od alkoholizma, neuroza i psihoza.

Što se tiče mogućnosti odlaska na teren, odnosno poseta korisnicima razlika se uočava u odnosu na ustanove i u odnosu na teritoriju gde se praksa obavljala, kao i u odnosu na broj studenata. Tokom prakse u centrima za socijalni rad u Nišu nijedan student nije imao mogućnost za terensku posetu, dok su u drugim gradovima (Vranje, Leskovac, Bor) studenti imali tu mogućnost. Razlog tome može biti i broj studenata koji praksu realizuje $\mathrm{u}$ istom trenutku u jednoj ustanovi pošto je u navedenim gradovima broj studenata bio manji (najviše pet). Što se tiče Centra za porodični smeštaj i usvojenje u Nišu, neki studenti (oko polovina njih) imali su priliku da posete hraniteljske porodice (jednu, dve ili tri), dok drugi nisu imali tu mogućnost. U ovom slučaju, to je imalo veza sa organizacijom vremena i aktivnosti od strane mentora, a razlozi koji su mentore opredelili za to nisu poznati. U drugim ustanovama u kojima je praksa realizovana terenske posete nisu deo posla socijalnog radnika.

Neki studenti aktivnosti tokom prakse opisuju kao „vrlo oskudne” i navode da su imali „ograničene mogućnosti” za učestvovanje u aktivnostima. 


\subsection{Problemi i izazovi sa kojima su se studenti susretali tokom prakse}

U izveštajima studenata, kao karakteristično se ističe da se nisu susreli ni sa kakvim problemima tokom realizacije prakse u Centru za porodični smeštaj i usvojenje Niš. Iznosili su brojne pohvale na račun odnosa zaposlenih prema njima i njihove spremnosti da im odgovore na sva pitanja.

„, Radnici ovo ustanove su bili obavešteni, organizovani i znali su kako da funkcionišu, kako bi i nas uveli u samu suštinu posla. " (student druge godine)

Kada su u pitanju problemi sa kojima su se studenti susretali tokom realizacije prakse u drugim ustanovama, a pre svega u centrima za socijalni rad, mogu se izdvojiti dve grupe problema: tehnički i organizacioni i oni koji su povezani sa radom mentora.

\subsection{Tehnički i organizacioni problemi:}

- prostorna ograničenja - nedovoljno prostrane kancelarije u nekim centrima za socijalni rad (pored voditelja slučaja i korisnika, u kancelarije je mogao biti prisutan jedan, a često nijedan student)

- nedovoljan broj vozila (ustanove nemaju dovoljan broj vozila što je onemogućilo da neki studenti realizuju terenske posete korisnicima)

- nedovoljan broj stručnih radnika (u nekim ustanovama zaposleno je svega nekoliko stručnih radnika, koji zbog brojnih obaveza nisu mogli da se posvete adekvatno svakom studentu)

- nedovoljno vremena (studenti ističu da su u nekim ustanovama proveli svega dan-dva što nije bilo dovoljno da se upoznaju sa svojom budućom profesijom).

\subsection{Problemi koji se odnose na rad mentora:}

- nedovoljno organizovane aktivnosti i nemogućnost studenata da učestvuju u konkretnim aktivnostima

- (ne) motivisanost nekih mentora (,,nezainteresovanost mentora “, , uopšte nisu bili motivisani“, , samo površno su nam davali odgovore na pitanja")

- nepripremljenost mentora i neobaveštenost da će studenti realizovati praksu (studenti navode da su neke ustanove prvi put bile u prilici da prihvate studente na praksu pa nisu bile dobro organizovane, niti su svi zaposleni bili obavešteni zbog čega su negodovali).

Kada se govori o problemima treba posmatrati kontekst u kom rade stručni radnici u ustanovama socijalne i zdravstvene zaštite. Neadekvatni uslovi rada (prostor, nedostupnost službenih automobila), manjak kadrova koji je delom uzrokovan i zabranom zapošljavanja u javnom sektoru koja je na snazi od 2013. godine, povećan obim posla su prepreke sa kojima se oni svakodnevno suočavaju. Među nepovoljnim 
organizacionim faktorima treba naglasiti znatno povećan broj slučajeva u odnosu na normu (na godišnjem nivou mogu imati oko 100 slučajeva), kao i način dokumntovanja rada sa korisnicima jer administrativni poslovi dodatno usložnjavaju posao zaposlenih (Žegarac, 2014). Sve ovo može uticati na motivisanost mentora koji, pored redovnih poslova, obavljaju i ovaj odgovoran zadatak, kao i na kvalitet mentorskog rada. Takođe, dobrovoljnost, izostanak naknade za ovu ulogu i nastojanje da se mentori motivišu kroz profesionalnu solidarnost i isticanje normativnog uređenja obaveze da ,prate, umeravaju i podržavaju studente na stručnoj praksi“ (Pravilnik o stručnim poslovima u socijalnoj zaštiti, čl.10) mogu rezultirati izostankom motivacije mentora i doživljajem da im ta uloga predstavlja samo dodatno opterećenje.

Druga istraživanja koja su došla do istog rezultata kao jednu od preporuka za unapređenje prakse ističu pripremu (zajedničke sastanke, sačinjavanje jasnog protokola prakse, edukaciju budućih mentora, smanjenje obima posla mentorima tokom trajanja prakse, senzibilizacija mentora za potrebe, strahove, očekivanja studenata) i podršku mentora tokom trajanja prakse (Urbanc, Buljevac, Vejmelka, 2016). Kao značajan vid podrške mentorima ističu se supervizijski sastanci mentora i nastavnika sa fakulteta (Urbanc, 2003).

Kada su u pitanju izazovi sa kojima su se studenti susretali na praksi, prepoznaju se slični izazovi u svim ustanovama, a pre svega se tiču samih studenata: nedovoljna pripremljenost, suočavanje sa novim situacijama, (ne)spremnost za kontakt sa korisnicima, briga u odnosu na spopstvene kompetencije.

“Izazov je bio savladati svoje reakcije.” (studentkinja druge godine)

"Izazov za socijalne radnike generalno i mene lično je prihvatanje da se ne može svima pomoći, i da je na nama da damo sve od sebe." (studentkinja druge godine)

Izazovi su često vezani za kontakt sa decom koja imaju razvojne smetnje, određene oblike invalideta, hronične bolesti, adolescentima koji su učinili određeno krivično delo, odraslima koji imaju probleme vezane za mentalno zdravlje ili bolesti zavisnosti. Nekima od studenata je to bio prvi neposredni kontakt sa decom, mladima i odraslima ovih karakteristika. Studenti su navodili da su u prvom kontaktu sa ovim korisnicima osećali ,strah“ i ,nekompetentnost". Iznosili su zapažanja da nisu imali dovoljno informacija o karakteristikama ovih korisnika, da nisu bili pripremljeni na koji način ostvariti komunikaciju sa njima, „šta se sme, a šta ne“ i da bi im takva priprema umnogome umanjila nelagodu prilikom prvog kontakta.

Nekoliko studenata navelo je da se nije susrelo sa problemima i izazovima tokom realizacije prakse, a kao glavni razlog za to navodili su dobar odnos sa mentorom i drugim zaposlenima u ustanovi:

„Ne postoje konkretni problemi sa kojima sam se susretala, jer sam, pre svega imala dobru komunikaciju sa svojim mentorom koji mi je dosta pomogao da savladam sve ono što nisam znala. " (studentkinja treće godine) 


\subsection{Pozitivna iskustva studenata tokom prakse}

Bez obzira na sve navedene probleme koji se pojavljuju u vezi sa radom mentora, kada su u pitanju pozitivna iskustva, studenti ipak najčešće navode odnos koji su imali sa mentorima. Prema njihovim rečima veliki broj socijalnih radnika sa kojima su sarađivali bio je motivisan da im prikažu sve strane svog posla, da sa njima diskutuju o slučajevima koje trenutno vode, kao i da ih upoznaju sa zanimljivim primerima iz ranije prakse. Studenti su se najčešće osećali slobodno da postavljaju pitanja na koja su ugalvnom dobijali iscrpne odgovore. Upravo zbog značaja odnosa sa mentorom, mentorstvo treba unaprediti i prevazići postojeće probleme, kako bi svi studenti, a ne samo neki od njih, imali mogućnost da ovakav odnos izgrade.

„Pozitivno je to što sam se osećala slobodnom da postavljam pitanja i ublažila neke svoje strahove koje sam imala u vezisa svojim budućim zanimanjem. " (studentkinja druge godine)

Pozitivan utisak na studente ostavio je i pristup koji zaposleni imaju prema korisnicima. Ovakva iskustva se najčeće odnose na Zavod za vaspitanje dece i omladine, Centar za porodični smeštaj i usvojenje i Dom za decu bez roditeljskog staranja. $\mathrm{Na}$ studente je pozitivno delovala atmosfera u Zavodu za vaspitanje dece i omladine koja se ogledala u toplom, ali i profesionalnom odnosu socijalnog radnik prema korisnicima. Sposobnost zaposlenih da uspostave prijateljski odnos, a pritom ne izgube autoritet delovala je motivišuće na studente da se bave ovim poslom.

"Pozitivno iskustvo će svakako obeležiti sam nastup i odnos zaposlenih kako prema nama tako i prema samim korisnicima koji borave kod njih. Odnos prema nama je bio obogaćen entuzijazmom da nam prenesu što više iskustva i znanja i dočaraju što približniju sliku njihovog posla. Odnos prema korisnicima je na vrlo lepo definisanom profesionalnom ali i na prijateljskom nivou, sto je svakako vredno pažnje s obzirom na to da je takve granice teško uspostaviti u ovakovom poslu." (student druge godine)

Pozitivna iskustva u svim ustanovama odnosila su se na mogućnost da prisustvuju ili čak i učestvuju u radu socijalnog radnika sa korisnicima. Tu pre svega studenti ubrajaju odlazak na teren, kao što je poseta hraniteljskoj porodici, prisustvo trijaži, intervju sa korisnicima, ali i uvid u dokumentaciju.

„,Najznačaniji događaj tokom prakse je upravo izlazak na teren, odnosno poseta hraniteljskoj porodici, jer smo upravo tada dobili mogućnost da ono o čemu smo učili i što smo znali isključivo iz teorije, sagledamo sa druge, ozbiljnije strane i da vidimo kako to izgleda u praksi." (studentkinja druge godine)

\subsection{Prikaz eventualnog nesklada između očekivanja i realnosti}

Što se tiče nesklada između očekivanja i realnosti, studenti su istakli da su u centrima za socijalni rad to loši uslovi rada. Neočekivano male kancelarije, sa većim brojem zaposlenih, u kojima se nalazilo nekada i više stranaka istovremeno nisu bile prijatno radno okruženje. Osim toga, studenti su očekivali više empatije, zalaganja pa čak i stručnosti u radu nekih socijalnih radnika. 
„Slaba zainteresovanost, pa čak i nestručnost nekih socijalnih radnika (po mom mišljenju) jako su me začudile. Pretpostavljam da je ovakva situacija zbog preobimnog $i$ psihički teškog posla." (student druge godine)

Donekle povezano sa pomenutim zapažanjima jeste i to da je posao socijalnog radnika u centru za socijalni rad zahtevniji nego što su očekivali.

„, Stres zanimanja je znatno veći od očekivanog, kako zbog pritiska na same zaposlene tako $i$ zbog prirode samog zanimanja i stresa koji nastaje kao posledica suočavanja sa problemima samih korisnika. Radni uslovi u kojima se radi su znatno gori od očekivanih. Sredstva i mogućnosti za pomoć su takodje znatno ograničene $i$ svedene na minimum, što donekle vezuje ruke onima koji su zaposleni u delatnosti socijalne zaštite. " (studentkinja druge godine)

Osim toga studenti zapažaju da je veliki deo posla administrativnog karaktera i da stručni radnici, suprotno očekivanjima, najveći deo vremena provode posvećeni tome, a ne terenskom radu.

Kada je u pitanju Centar za porodični smeštaj, studenti su imali različita iskustva u odnosu na očekivanja sa kojima su otišli u ovu ustanovu. Određen broj studenata nije imao očekivanja od prakse u ovoj ustanovi upravo zbog nesklada koji su iskusili u centru za socijalni rad. Oni kod kojih je bilo očekivanja, primetili su da je posao u ovj ustanovi zahtevniji nego što su mislili:

„, Slušajući iskustva stručnih radnika zaključila sam da je njihov posao znatno teži nego što se može pretpostaviti upravo zbog neočekivanih okolnosti koji se mogu javiti (poput toga da dete koje je zlostavljano u porodici lažno svedoči o prirodi svojih povreda kako bi svejedno ostalo uz roditelje). “ (studentkinja druge godine)

Što se tiče Doma za decu bez roditeljskog staranja i Zavoda za vaspitanje dece i omladine studenti su u najvećoj meri izrazili nesklad između svojih očekivanja i načina na koji ove ustanove funkcionišu. U najvećem broju slučajeva naveli su pravila koja važe u Zavodu, kao što su mogućnost korisnika da samostalno napuste ustanovu i to da dobijaju nedeljni džeparac. U pogledu Doma, ono što nisu očekivali jeste boravak dece sa smetnjama u razvoju.

„,Nesklad se javio u Domu za vaspitanje dece i omladine gde sam očekivala da ta deca imaju veća ograničenja nego što je zapravo situacija. Često prilikom pomišljanja na takvu vrstu institucija zamislim nasilno ophođenje vaspitača prema deci, što je sušta suprotnost. " (studentkinja druge godine)

Osim ovoga, nesklad se pojavio i u pogledu otvorenosti korisnika Zavoda da ostvare kontakt sa studentima. Većina studenata nije očekivala da će moći da uspostavi bilo kakvu komunikaciju sa ovim mladim osobama:

„Očekivala sam da sa decom koja tamo borave ne može da se uspostavi bilo kakav kontakt, međutim, oni su baš željni komunikacije sa drugima i teže da se uklope u društvenu sredinu i da se oslobode etikete problematične dece." (studentkinja druge godine)

Većina studenata koja je imala pozitivna očekivanja navela je da nije bilo nesklada nakon obavljene prakse. Prema njihovim rečima socijalni radnici su pokazali očekivan stepen želje i zalaganja da pomognu deci koja se nalaze u sistemu: 
"Ne postoji nesklad između očekivanja i realnosti, dok smo bili na praksi videla sam da su se svi trudili da pomognu deci koja su u sistemu alternativne zaštite, kako mladjima, koje su savetovali i vaspitavali, tako i starijima kojima su obezbedili stipendiju ili zaposlenje." (studentkinja druge godine)

Iz navedenog se može zaključiti da su realizacijom prakse studenti izmenili svoje viđenje ustanova koje su posetili, te da su obogatili svoja znanja o tome kako institucije socijalne i zdravstvene zaštite funkcionišu u praksi.

\subsection{Prikaz povezanosti između znanja i veština stečenih tokom studija i njihove primene tokom prakse}

Kada su u pitanju percepcije studenata o povezanosti između znanja i veština stečenih tokom studija i njihove primene tokom prakse, najveći broj studenata smatra da su im dosadašnje studije i te kako omogućile da razumeju procese koje su videli u praksi. Ističu da su kroz različite teorijske i časove vežbi stekli sliku o svojoj budućoj profesiji, o mogućim izazovima koji ih čekaju u radu, ali i načinima prevazilaženja potencijalnih smetnji. Zapažaju i da im je praksa omogućila da preispitaju svoja postojeća znanja i prepoznaju šta je to što im nedostaje, a što je značajno da tokom nastavka studija steknu. Takođe, studenti imaju jasan uvid da su tek na polovini svojih studija i da im tek predstoji sticanje specifičnih znanja i veština, neophodnih za kompetentno bavljenje profesijom socijalnog rada.

Kao predmete iz kojih su stekli znanja i veštine koje su mogli da primene $\mathrm{u}$ praksi studenti su navodili: Socijalni rad sa pojedincem, Teorije socijalnog rada, Socijalni rad sa grupom, Psihologiju ličnosti, Razvojnu psihologija, Nasilje, vaspitno zanemarivanje i zlostavljanje dece, Upravno pravo, Porodično pravo, Porodicu i porodične odnose, Sociologiju porodice.

Studenti su prepoznali da su u dosadašnjim studijama imali priliku da steknu najviše znanja o poslovima centra za socijalni rad, kao i centru za porodični smeštaj, dok su njihova znanja o specifičnosti drugih ustanova socijlne i zdravstvene zaštite još uvek nedovoljna. U skladu sa tim, studenti navode da su se u aktivnostima u centrima za socijalni rad i Centru za porodični smeštaj osećali znatno kompetentnije, dok su u aktivnostima koje su realizovali u Domu za decu bez roditeljskog staranja, Zavodu za vaspitanje dece i omladine, zdravstvenim ustanovama bili znatno neinformisaniji i samim tim nesigurniji. Ističu da im je nedostajalno znanja o specifičnostima dece koja imaju smetnje u razvoju, kao i da o tretmanu mladih koji su počinili krivična dela, tokom studija nisu imali priliku da se informišu. Ako se uzme u obzir to da su nastavnim planom predmeti koji se bliže bave ovim populacijama, predviđeni za naredne semestre ili da su neki od predmeta izbornog karaktera jasno je ovakvo zapažanje studenata.

\subsection{Predlog daljeg pravca razvoja prakse socijalnog rada}

Predlozi za unapređenje prakse mogu se grupisati u dve oblasti: predlozi koji su vezani za organizaciju prakse i predlozi koji se odnose na rad mentora. 
U prvoj oblasti, najveći broj predloga studenata se odnosi na produženje trajanja prakse. Ovaj predlog se odnosi na sve institucije u kojima je praksa realizovana. Jedan od razloga za to može biti i to što je vreme trajanja prakse za neke studente bilo kraće nego što je predviđeno programom. Već navedeni razlog tome je disproporcija broja studenata u odnosu na broj mentora u nekim ustanovama.

Unapređenje planiranja i realizacije prakse odnosi se na bolju pripremljenost studenata i mentora, jasnije definisane zadatke, aktivnosti, ishodi prakse, pravljenje plana.

"Uputstva, kako studentima tako i zaposlenima u ustanovama, u vidu davanja nekih smernica ili zadataka koje treba zajedno da odradimo svakako bi konkretizovale samu realizaciju prakse. "(student treće godine)

Iskustvo odlaska na teren, prisustvovanje intervjuima sa korisnicima, popunjavanje dokumentacije su iskustva sa prakse koja studenti prepoznaju kao jako značajna i upravo se kao skup preporuka izdvaja učestvovanje u „konkretnim” aktivnostima kao što su ove navedene. Studenti u ovome prepoznaju benefite kako za sebe, tako i za mentore (,pomoć pri vođenju dokumentacije tj. administrativnih poslova socijalnim radnicima bi olakšala posao, a studentima donela dodatno iskustvo", student druge godine). Neki od studenata naglašavaju da odlazak u terenske posete treba uvesti kao obavezni deo prakse.

$\mathrm{S}$ obzirom na to da mogućnosti studenata u različitim, a nekada i u istim ustanovama za učešće u ovakvim aktivnostima nisu bile jednake, jedan broj studenata naglašava upravo ,izjednačavanje mogućnosti” i u formi i u sadržaju prakse.

„Svim studentima bi trebalo dati jednaku šansu, a ne da se ostavlja prostor za nejednako tretiranje od strane različitih mentora." (student druge godine)

Takođe, formiranje manjih grupa studenata studenti prepoznaju da to doprinosi efikasnijem radu, kao i većoj posvećenosti mentora.

Izdvajaju se i neki predlozi koji su specifični u odnosu na konkretne ustanove: prisustvo radionicama u okviru programa pripreme hranitelja ili redovnim godišnjim obukama (Centar za porodični smeštaj i usvojenje), veće uključivanje u rad sa korisnicima u ustanovi (Zavod za vaspitanje dece i omladine, Dom za decu bez roditeljskog staranja).

U drugoj oblasti se izdvajaju pitanje motivacije i pripreme mentora. Studenti smatraju da se treba ozbiljnije baviti motivacijom mentora (potrebna je veća zainteresovanost, angažovanje, „ozbiljniji pristup” mentorstvu). Takođe, kao značajno se prepoznaje unapred odrediti mentora za studente koji će pratiti rad studenata tokom cele realizacije prakse. Iako je to predviđeno programom studija i Standardima praktične obuke u obrazovanju socijalnih radnika, nije uvek bilo primenjivano. Odnosno, svaki student je formalno imao mentora koji je popunjavao izveštaj, ali tokom same realizacije prakse ovo nije uvek poštovano. Bolja priprema mentora se odnosi na blagovremeno obaveštavanje mentora o angažovanju, zadacima, očekivanjima, dobijanje instrukcija ili predloga za zadatke i aktivnosti u koje bi mogli da uključe studente.

Jedan (manji broj) studenata ne daje predloge za unapređenje razvoja prakse, već navode da su potpuno zadovoljni realizacijom prakse, da je praksa uspešna, kao i da ništa ne bi menjali u realizaciji prakse. 


\section{Zaključak i preporuke}

Rezultati evaluacije pokazuju da je realizovana stručna praksa delimično, ali ne i potpuno usklađena sa ciljevima, očekivanim ishodima i sadržajima prakse koji su predviđeni studijskima programom. Upravo i neki dobijeni predlozi za unapređenje prakse (duže trajanje, prirema i jasna zaduženja mentora, plan prakse) jesu u skladu sa onim što program prakse i Standardi praktične obuke u obrazovanju socijalnih radnika predviđaju, ali što iz različitih razloga nije bilo moguće sprovesti tokom realizacije prakse u školskoj godini u kojoj je evaluirana praksa.

Potrebno je uraditi i reviziju prakse i preispitati njenu usklađenosti sa drugim predmetima koje predviđa nastavni plan. To je posebno značajno ukoliko se uzme u obzir to da su neki predmeti koji se bliže bave određenom populacijama predviđeni u semsetrima nakon realizacije prakse ili su izbornog karaktera.

$\mathrm{Na}$ osnovu rezultata zaključuje se da je potrebno sprovesti obuku za mentore koji učestvuju u realizaciji prakse, kao i organizovati periodične sastanke sa mentorima. To bi bili načini da se unaprede njihove kompetencije u vezi sa mentorstvom, ali i prilika da se razmene iskustva i primeri dobre prakse. Podrška ovog tipa može pozitivno uticati na motivaciju mentora. Takođe, studenti iskazuju potrebu za temeljnijim organizovanjem priprema, ne samo mentora nego i samih studenata, kako bi prilagodili očekivanja, umanjili lične izazove i adekvatnije se pripremili za zadatke i očekivane ishode stručne prakse.

Kvalitet stručne prakse bi značajno bio unapređen i angažovanjem nastavnika praktičnih veština koji koji se, u saradnji sa nastavnicima primenjenih disciplina iz oblasti socijalnog rada, bavi koordinacijom između visokoškolske ustanove, organizacija u kojima se realizuje praksa, studenata i mentora, kao i upućivanjem, praćenjem i evaluacijom terenske prakse i praktične nastave (Hrnčić, Žegarac, Burgund, 2016: 129).

Dalji pravci razvoja stručne prakse na Departmanu za socijalnu politiku i socijalni rad u narednom periodu treba da budu usmereni ka što većem usklađivanju sa nastavnim planom i propisanim Standardima praktične obuke u obrazovanju socijalnih radnika.

\section{Literatura}

Hrnčić, J., Žegarac, N., Burgund, A. (2016). Standardi praktične obuke u obrazovanju socijalnih radnika. U: N. Žegarac (ur.) Standardi za obrazovanje socijalnih radnika u Srbiji-Razvoj kompetencija za kvalitetnu profesionalnu praksu (123-132). Beograd: Univerzitet u Beogradu, Fakultet političkih nauka.

IFSW/IASSW. (2014). Global Definition of the Social Work Profession. preuzeto sa (01.10.2019.) https://www.ifsw.org/what-is-social-work/global-definition-of-socialwork/.

Lager, P. B., Cooke Robbins, V. (2004). Field education: Exploring the future, expanding the vision. Jurnal of Social Work Education 40 (1), 3-12.

Papouli, E. (2014). Field Learning in Social Work Education: Implications for Educators and Instructors. Field Educator 4(2). 
Pravilnik o stručnim poslovima u socijalnoj zaštiti (2013). Službeni glasnik RS, br. 42/2013.

Urbanac, K. (2003). Značaj terenske nastave za razvoj profesionalnog identiteta socijalnih radnika. Ljetopis socijalnog rada 10(1), 61-70.

Urbanc, K., Buljevac, M.,Vejmelka, L. (2016). Teorijski i iskustveni okvir za razvoj modela studentske terenske prakse u području socijalnog rada. Ljetopis socijalnog rada 23(1). 5-38.

Žegarac, N. (2014). U lavirintu socijalne zaštite - Pouke istraživanja o deci na porodičnom i rezidencijalnom smeštaju. Beograd: Univerzitet u Beogradu Fakultet političkih nauka Centar za istraživanja u socijalnoj politici i socijalnom radu.

\title{
EVALUATION OF PROFESSIONAL PRACTICE IN SOCIAL POLICY AND SOCIAL WORK BACHELOR STUDIES
}

\author{
Ljiljana Skrobić, Bojana Pucarević, Ivan Anđelković \\ University of Niš, Faculty of Philosophy, Department of Social \\ Policy and Social Work
}

\begin{abstract}
Since social work is a practice-based profession, professional practice plays an important part in the education of social workers. Students derive numerous benefits form professional practice, aimed at their professional and personal growth alike. Therefore, it is of central importance to continuously evaluate and improve professional practice as a part of the Social Work studies. The purpose of this paper is to present the process and the results of the professional practice evaluation which is a part of the Social Policy and Social Work studies at the Faculty of Philosophy in Niš. The evaluation was performed by means of content analysis of the students' professional practice reports. The evaluation was conducted for the professional practice of the 2018/2019 school year. The results indicate that the professional practice partly, but not completely, matches the goals, the expected outcomes and contents defined in the study program. Further directions for professional practice development should include better harmonization with the study program and the issued Standards for practical training and education of social workers.
\end{abstract}

Keywords: social work, education, professional practice, students.

\section{Citiranje članka:}

Skrobić, Lj., Pucarević, B. i Anđelković, I. (2019). Evaluacija stručne prakse na Osnovnim akademskim studijama socijalne politike i socijalnog rada. Godišnjak za pedagogiju, 4(2), 31-43 
